\title{
The Pathogenesis of Vestibule Cochlear Nerve Disease in Herpes Zoster Oticus
}

\author{
Navneet Gupta ${ }^{1 *}$, Reeta Gupta ${ }^{2}$, Abhaya Lenka ${ }^{3}$, Kalu Rauta $^{3}$ and Aquib Manzoor Dar ${ }^{3}$ \\ ${ }^{1}$ Department of ENT, Acharya Sri Chander College of Medical Sciences \& Hospital, India \\ ${ }^{2}$ Department of Dermatology, Acharya Sri Chander College of Medical Sciences \& Hospital, India \\ ${ }^{3}$ Consultant Audiologist \& Speech \& Language Pathologist, JK Electronic Ears, Prime Speech \& Hearing Clinic, India
}

Submission: December 21, 2017; Published: January 03, 2018

*Corresponding author: Navneet Gupta, Department of ENT, Acharya Sri Chander College of Medical Sciences \& Hospital, India, Tel: +91-9419261310; Email: navneetaryan@gmail.com

\section{Abstract}

Objectives: Audio logical assessment in patients with herpes zoster oticus were performed to determine the biologic features of the varicella zoster virus (VZV) and the pathogenesis of vestibule cochlear nerve disease in herpes zoster oticus.

Study Design: A retrospective study review of 60 patients with herpes zoster oticus was designed in order to determine the classic characteristics of vestibule cochlear nerve disease associated with the syndrome.

Results: Among 60 patients, 30 had a complaint of cochlear symptoms, were undergone for audio logical assessment. Among those 60 patients, $37(22.2 \%)$ showed deviations in the audio logical findings. The incidence of cochlear symptoms in herpes zoster oticus was not related to the severity of facial paralysis. The incidence of patients with isolated high frequency hearing loss is statistically increased with age.

Conclusion: Mild or moderate cochlear symptoms with high frequency hearing loss were related to age, and severe vestibular symptoms were related to the severity of facial paralysis after onset of herpetic symptoms.

\section{Introduction}

In 1907, James Ramsay Hunt first postulated that the etiology of herpes zoster oticus was the reactivation of the varicella zoster virus (VZV) in the geniculate ganglion [1]. The strict definition of the Ramsay Hunt syndrome is peripheral facial nerve palsy accompanied by an erythematous vesicular rash on the ear (zoster oticus) or in the mouth. J Ramsay Hunt, who described various clinical presentations of facial paralysis and rash, also recognised other frequent symptoms and signs such as tinnitus, hearing loss, nausea, vomiting, vertigo, and nystagmus. He explained these eighth nerve features by the close proximity of the geniculate ganglion to the vestibule cochlear nerve within the bony facial canal [2].

In patients with herpes zoster oticus, disorders of the eighth cranial nerve are frequently observed. Hearing loss is usually mild to moderate, and the audio logical data suggest cochlear and/or retro cochlear involvement [3]. The vestibular symptoms are sometimes severe, and a study showed that both the superior and inferior divisions of the vestibular nerve could be widely affected [4]. Kuhweide et al. reported that the infection may spread to the cochlea vestibular system through the vestibulofacial communicating branch or via perineural tissues within the internal auditory canal [5]. Evidence of inflammation within the auditory and vestibular nerves and the labyrinth has been noted on post-mortem examinations of patients with herpes zoster oticus [6]. Murakami et al., also reported that the presence of VZV in the middle ear mucosa of patients with herpes zoster oticus suggested the arrival of VZV in the labyrinth through dehiscence of the facial nerve canal, creating a passage through the oval and/or round window [7].

The diagnosis is usually made based on history and physical examination. Enhancement of the seventh and eighth cranial nerves on gadolinium-enhanced, T1-weighted MRI can be observed. Hemorrhage of the cochlear nerve and destruction of the apex of the organ of Corti have been reported. This study focused on the audio logical findings by pure tone audiometry and impedance audiometry of patients with herpes zoster oticus. The findings were compared with the clinical severity of facial paralysis and patient age to clarify the pathogenesis of vestibule cochlear nerve disease in herpes zoster oticus.

\section{Materials and Methods}

To establish a relationship between adverse affect of Herpes Zoster Octicus and Hearing system, we collected data of pure tone audiometry (PTA) and Impedance Audiometry of 60 
patients with herpes zoster octicus, who had visited ASCOMS for a hearing check up over past 2 years. The patients who had prior histories of hearing impairment or vertigo due to other causes were excluded from this study. The patients were classified according to severity of facial paralysis, based on the system proposed by House and Brackmann. Patients with symptoms of cochlear dysfunction (hearing impairment, tinnitus, and ear fullness) underwent audio logical tests. Pure tone audiometry was conducted at frequencies of $0.25,0.5,1,2,4$, and $8 \mathrm{kHz}$. Acoustic thresholds of the affected ears were compared with those of the contra lateral (unaffected) ears at each frequency level.

\section{Results}

Sixty patients were included in the study (33men and 27 women; age ranges 30 to 60 years). Thirty of those patients had complaint of cochlear symptoms: hearing loss, ear fullness, tinnitus, or hyperacusis. None of the patients had spontaneous or positional nystagmus on physical examination throughout hospitalization. The mean acoustic thresholds and standard errors at $0.25,0.5,1,2,4$, and $8 \mathrm{kHz}$ in the affected ear were calculated to be compared with those of the unaffected ear (Figure 1). The mean acoustic threshold at all frequencies showed a statistical difference between the affected ear and the normal ear. The difference of mean acoustic threshold between the affected ear and the unaffected ear increased as examination frequency was made higher.

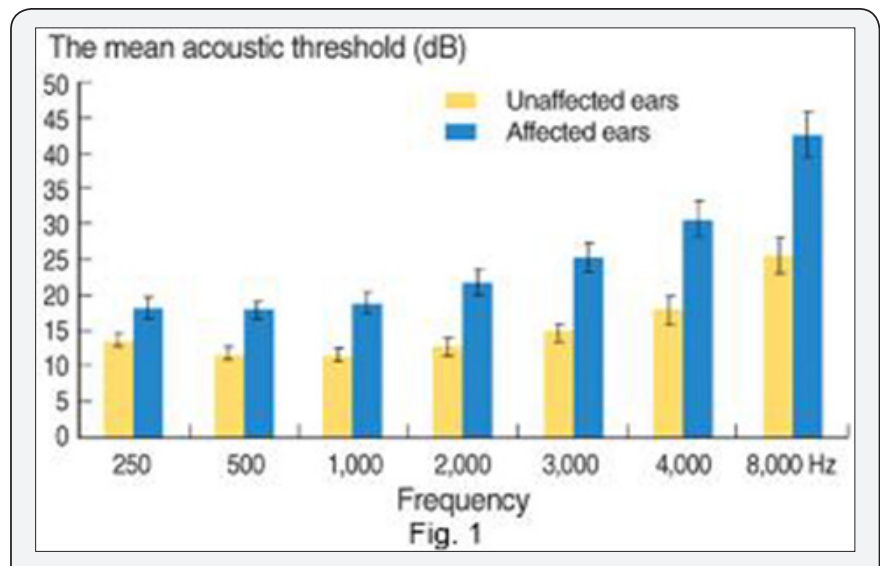

Figure 1: The mean acoustic threshold and standard errors of affected ears and unaffected ears of patients with herpes zoster oticus.

The mean acoustic threshold at all frequencies examined exhibited a statistically significant difference between the affected ear and the unaffected ear. The difference in the mean acoustic threshold between the two increased in parallel with frequency. More severe hearing loss was evident at high frequencies ( $4 \mathrm{kHz}$ and $8 \mathrm{kHz}$ ) in the affected ear. Among 30 patients with cochlear symptoms, 22 patients were male, and 8 were female. There were no significant differences noted with regard to gender and severity of facial paralysis. All the patients were undergone through impedance audiometry. There was no significant results obtained but there was elevation in both ipsi and contra lateral acoustic reflexes in the affected ear.

\section{Discussion}

Auditory and vestibular disturbances are common findings in patients with herpes zoster oticus. Many reports concerning vestibule cochlear nerve disease associated with herpes zoster oticus state that the classic syndrome described by Ramsay Hunt is not common and is no doubt a more complicated disease than the original description as "geniculate ganglionitis". In our study, the incidence of patients complaining of hearing loss was $50 \%$, and the incidence of patients who showed audio logical abnormalities was $60 \%$. Patients with audio logical abnormalities in speech frequency range could detect hearing disturbance, but in cases of isolated high frequency loss, the patients did not have auditory symptoms in general However, the incidence of hearing loss differs in the cases reported in the literature, ranging from $7 \%$, to $19.7 \%$ [8], to as high as $85 \%$ [9]. The presence of cochlear and retro cochlear patterns of hearing loss has been reported by various authors.

Wayman et al., [9] in a respective study of 186 patients with herpes zoster oticus-only seven of whom were studied in audio logical detail-recognized one patient with retro cochlear involvement, five with cochlear involvement, and one with both cochlear and retro cochlear involvement. Abramovich and Prasher [10] in another detailed audio logical examination of 13 patients with herpes zoster oticus, used electrocochleography and brainstem evoked potentials in addition to classic audio logical tests. Seven of the 13 patients with aural herpes zoster who demonstrated retro cochlear involvement could be classified as sensory, with some patients showing both sensory and neural signs. However, Kaberos et al., [3] studied 15 patients with herpes zoster oticus through the use of otoacoustic emission in addition to auditory brain-stem response and demonstrated retro cochlear involvement in eight patients. Only three patients had purely retro cochlear hearing loss; the other five patients had concomitant cochlear involvement. Tinnitus was present in 14 patients $(67 \%)$. Hearing Handicap was found in $86 \%$ of patients (of the 21 questionnaire responders \& Tinnitus handicap in $57 \%$ (of the 14 with tinnitus) [11]. Tinnitus was present in 14 patients (67\%)

\section{Conclusion}

The results of this study support the thesis that viral spread from the geniculate ganglion to the eighth nerve through the per neural sheath, and the connection between nerve fibber bundles in the internal auditory canal, are important factors in vestibule cochlear nerve disease in herpes zoster oticus. Clinical impact of herpes zoster could be magnified by age-related suppression in cell-mediated immunity.

\section{References}

1. Hunt JR (1907) On Herpetic Inflammations of the Geniculate Ganglion: A New Syndrome and its Complications. J Nerv Ment Dis 34(2): 73-96. 
2. Sweeney CJ, Gliden DH (2001) Ramsay Hunt Syndrome. J Neurol Neurosurgery Psychiatryn 71(2): 149-154

3. Kaberos A, Balatsouras DG, Korres SG, Kandiloros D, Economou C (2002) Audio Logical Assessment in Ramsay Hunt Syndrome. Ann Otol Rhinol Laryngol 111(1): 68-76.

4. Lu YC, Young YH (2003) Vertigo from Herpes Zoster Oticus: Superior or Inferior Vestibular Nerve Origin?. Laryngoscope 113(2): 307-11.

5. Kuhweide R, Van de Steene V, Vlaminck S, Casselman JW (2002) Ramsay Hunt Syndrome: Path Physiology of Cochlea Vestibular Symptoms. J Laryngol Otol 116(10): 844-848.

6. Blackley B, Friedmann I, Wright I (1967) Herpes Zoster Auris Associated with Facial Nerve Palsy and Auditory Nerve Symptoms: A Case Report with Histopathological Findings. Acta Otolaryngol 63(6): 533-550.

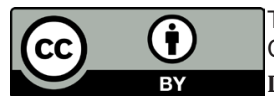

This work is licensed under Creative Commons Attribution 4.0 License DOI: $10.19080 /$ GJO.2018.12.555842
7. Murakami S, Nakashiro Y, Mizobuchi M, Hato N, Honda N, et al. (1998) Varicella-Zoster Virus Distribution in Ramsay Hunt Syndrome Revealed by Polymerase Chain Reaction. Acta Otolaryngol 118(2): 145-149.

8. Byl FM, Adour KK (1977) Auditory Symptoms Associated with Herpes Zoster or Idiopathic Facial Paralysis. Laryngoscope 87(3): 372-379.

9. Wayman DM, Pham HN, Byl FM, Adour KK (1990) Audio Logical Manifestations of Ramsay Hunt Syndrome. J Laryngol Otol 104(2): 104-108.

10. Abramovich S, Prasher DK (1986) Electrocochleography and BrainStem Potentials in Ramsay Hunt Syndrome. Arch Otolaryngol Head Neck Surg 112(9): 925-928.

11. Chiossoine Kerdel Juan A, Baguley David M, Stoddart Rachel L, Moffat David A (2000) An Investigation of the Audio Logic Handicap Associated with Unilateral Sudden Sensorineural Hearing Loss. American Journal of Otology 21(5): 645-651.

\section{Your next submission with Juniper Publishers will reach you the below assets}

- Quality Editorial service

- Swift Peer Review

- Reprints availability

- E-prints Service

- Manuscript Podcast for convenient understanding

- Global attainment for your research

- Manuscript accessibility in different formats ( Pdf, E-pub, Full Text, Audio)

- Unceasing customer service

Track the below URL for one-step submission https://juniperpublishers.com/online-submission.php 